\title{
To Determine the Correlation between D-Dimer and CD4+ T-Cell Count in HIV Treatment-Naive and Treatment-Experienced Patients in Port- Harcourt, Nigeria
}

\author{
Akhidue $\mathrm{DO}^{1}$, Akhidue $\mathrm{K}^{2}$, Alikor $\mathrm{C}^{2^{*}}$, Ejele $\mathrm{OA}^{3}$ \\ ${ }^{1}$ Department of Haematology, Federal Medical Center, Yenagoa, Nigeria \\ ${ }^{2}$ Department of Internal Medicine, University of Port Harcourt Teaching Hospital, Port Harcourt, Nigeria \\ ${ }^{3}$ Department of Haematology,University of Port Harcourt Teaching Hospital, Port Harcourt, Nigeria
}

DOI: $\underline{10.36348 / \mathrm{sjpm} .2020 . \mathrm{v} 05 \mathrm{i} 03.005}$

| Received: 22.02.2020 | Accepted: 02.03.2020 | Published: 08.03.2020

*Corresponding author: Chizindu Alikor

\section{Abstract}

Background: Reports suggest that HIV-infected patients have elevated D-dimer levels that may be related to chronic inflammation and coagulation abnormalities. Levels of D-dimer have also been reported to be higher in HIV treatmentnaïve patients compared to treatment- experienced patients. HIV infection has also been associated with a decrease in the number of both CD4+ and CD8+ T-cells resulting primarily from a combination of increased apoptosis and decreased lymphopoiesis. Methods: Eighty (80) subjects attending HIV clinic at the University of Port-Harcourt Teaching Hospital, Port Harcourt, Rivers state who satisfied the inclusion criteria were enrolled into the study. A commercial assay kit; ELISA Kit for D-Dimer (D2D) (manufactured by Uscn Life Science Incorporated ${ }^{\mathrm{R}}$ USA) was used with a TC96+ ELISA microplate reader (manufactured by Ceco diagnostic ${ }^{R}$ USA) to determine the D-dimer level. CD4 + T-cell count was evaluated using the Partec Cyflow counter-1, a single-platform, three-parameter (SSC plus two-colour fluorescence) desktop volumetric flow cytometer (manufactured by Sysmex Partec ${ }^{\mathrm{R}}$ Germany).Full blood count was carried out on the EDTA anticoagulated sample using the Horiba Abx Micros 60 Haematology Analyser (manufactured by Horiba instruments incorporated ${ }^{\mathrm{R}}$ USA). Results: The D-dimer level was found to be lower in HAART- experienced subjects $(288.35 \pm 129.12 \mathrm{ng} / \mathrm{ml})$ than HAART-naïve subjects $(389.85 \pm 217.61 \mathrm{ng} / \mathrm{ml}$. $)(\mathrm{P}=0.013)$.The mean CD4+ T-cell count of HAART-naïve subjects was $379.33 \pm 287.25$ cell/ul and for HAART-experienced subjects was $387.55 \pm 334.85$ cell/ul. Their mean difference was not statistically significant $(\mathrm{P}=0.906)$. Conclusion: It was observed that there was no correlation between D-Dimer and CD4+ T-cell count in HAART-naive and experienced subjects.

Keywords: Human immunodeficiency virus, Treatment-naive, Treatment-experienced, D-dime, CD4+T-cell.

Copyright @ 2020: This is an open-access article distributed under the terms of the Creative Commons Attribution license which permits unrestricted
use, distribution, and reproduction in any medium for non-commercial use (NonCommercial, or CC-BY-NC) provided the original author and sources
are credited.

\section{INTRODUCTION}

Globally, an estimated 35.3 (32.2-38.8) million people were living with HIV in 2012. An increase from previous years as more people are receiving the lifesaving antiretroviral therapy. There were 2.3 (1.9-2.7) million new HIV infections globally, showing a 33\% decline in the number of new infections from 3.4 (3.13.7) million in 2001. At the same time the number of AIDS deaths is also declining with 1.6 (1.4-1.9) million AIDS death in 2012, down from 2.3 (2.1-2.6) million in 2005 [1].

A comprehensive survey conducted in 2012, (NARHS plus II 2012) showed a decline in HIV prevalence in Nigeria to $3.4 \%$ from $4.1 \%$ in 2011. Similarly, based on projected HIV estimates for 2013, about 3,229,757 people live with HIV while it is estimated that 220,394 new HIV infections occurred in 2013. A total of 210,031 died from AIDS related cases. It is also estimated that a total of 1,476,741 required antiretroviral (ARV) drugs in 2013 out of which 639,397 are currently receiving treatment [2].

Nigeria's life expectancy has declined significantly. In 1991 the average life expectancy was 54 years for women and 53 years for men [3]. In 2010 the overall life expectancy had fallen to around 51.9 years [4].

Human immunodeficiency virus (HIV) is a retrovirus in the lentivirus family with a diameter of $100 \mathrm{~nm}$. It is a lipid-coated RNA virus with a reverse transcriptase [5]. Two types of HIV exist presentlyHIV-1 and HIV-2 and these two viruses have been identified as the primary cause of Acquired 
Immunodeficiency Syndrome (AIDS) [6, 7]. HIV-1 was first isolated in the early 1980s and is the major cause of AIDS in the world today [8]. HIV-2 which is similar to HIV-1 was later identified in the developing world [9].

Acquired immune deficiency syndrome (AIDS) was first reported in 1981 in Los Angeles, USA. In late 1982, the first cases of AIDS-like illness were reported in transfused patients [10]. By early 1984, the responsible virus, HIV-1, initially called human Tcell lymphotropic virus-1ll (HTLVIII)/lymphadenopathy associated virus (LAV) was identified [10].

HIV can be transmitted by sexual contact with an infected partner, parenteral drug use with a bloodcontaminated needle, exposure to infected blood or blood products, and perinatal exposure from an infected mother to her infant [11].

Approximately 80-95 percent of HIV infections in Nigeria are a result of heterosexual sex [12], while transmission through unsafe blood accounts for the second largest source of HIV infection in Nigeria [13]. The prevalence of HIV infection among blood donors varies from one geographical location to another. Egesie et al., in 2011 got a seroprevalence rate of $6.9 \%$ [13] and Ejele et al., in a study in port-harcourt got a seroprevalence rate of $1.4 \%$ [14]. Vertical transmission still remains important with around 75,000 babies born with HIV each year in Nigeria [15]. While, there are indications of increasing HIV prevalence among injection drug users (IDU) in Nigeria [16].

HIV infection leads to a decrease in the number of both CD4+ and CD8+ T-cells resulting primarily from a combination of increased apoptosis and decreased lymphopoiesis [17, 18]. The many mechanisms that contribute to HIV-associated lymphocyte apoptosis include chronic immunologic activation; gp120/160 ligation of the CD4 receptor; enhanced production of cytotoxic ligands or viral proteins by monocytes, macrophages, B cells, and CD8+ T-cells from HIV-infected patients that kill uninfected CD4+ T-cells; and direct infection of target cells by HIV, resulting in apoptosis [17].

CD4+ T-cell count is the strongest predictor of disease progression and survival [19-21]. Therefore, obtaining accurate, reliable, and affordable CD4+ Tlymphocyte counts is essential. It is also crucial in determining when to start or change antiretroviral (ARV) therapy and while monitoring ARV therapy [22].

HIV infection is known to result in increased levels of proinflammatory cytokines, such as tumor necrosis factor (TNF), interleukin-1 (IL-1), and interleukin-6 (IL-6), which can contribute to the development of a procoagulant state by increased levels of factor VIII and decreased levels of protein S [3, 24].

The hypercoagulable state created by HIV infection might induce thrombus formation and subsequent fibrinolysis will give rise to a raised $\mathrm{D}$ dimer level [25].

The D-dimer antigen is a specific marker of fibrin clot formation and fibrinolysis, which serves as a clinically useful marker for exclusion of VTE, and evaluation of the risk of VTE recurrence in select populations [25].

An increased risk of death was found to be associated with higher levels of high-sensitivity Creactive protein (hs CRP), interleukin 6 (IL-6), and Ddimers and the level of these biomarkers were reduced by effective ARV therapy [6].

Kuller et al., found that HIV-induced activation of inflammation and a hypercoagulable state increases the risk of death among HIV-positive patients, and that interrupting ARV therapy further increases this risk [27]. HIV infection has emerged as a well recognized prothrombotic condition. Crum-cianflone et al., reported that venous thromboembolism (VTE) occurs more commonly among HIV-infected persons than in the general population, and they often occur in relatively young patients [28].

The mechanisms by which HIV infection causes thrombosis is multifactorial and complex.

Several coagulation abnormalities have been reported among $\mathrm{HIV}$-infected patients including the presence of antiphospholipid antibodies, increased levels of von Willebrand factor, elevated homocysteine, and deficiencies of protein C, protein S, Antithrombin III, and heparin cofactor II [8]. It has also been observed that alterations in several thrombophiliac components correlate with $\mathrm{HIV}$-induced immunodeficiency and thereby with a low CD4+ T-cell count [23, 24, 29].

Activation of monocytes by microbial products and high level of CRP both of which up-regulates expression of tissue factor (TF) has also been proposed as possible mechanism of thrombus formation in HIV $[30,31]$.

HIV-infected persons are now living longer in the era of highly active antiretroviral therapy (HAART), as a result of significant advances in both the understanding of the immunopathogenesis and the clinical management of AIDS [11]. Patients with HIV have multiple risk factors and are at increased risk for VTE, compared with the general population [28]. It is imperative that all risk factors for VTE be identified and incorporated into medical decision making for high-risk patients, including those with HIV. 
The aim of this study was to evaluate the Ddimer level and CD4+ $\mathrm{T}$ cell count in HIV-positive treatment-naïve and treatment-experienced patients. Also to evaluate the relativity or correlation if any between D-dimer and CD4+ T-cell count. Since both may be independent predictors or markers of disease severity and progression in HIV. It is hoped that the outcome of this study will add to our knowledge, and at the same time help improve the standard of management of our HIV patients thereby reducing morbidity and mortality.

\section{MATERIALS AND METHODS}

This comparative cross-sectional study was conducted on HIV treatment- experienced patients on HAART, and treatment-naïve HIV patients, all attending HIV clinic at the University of Port-Harcourt Teaching Hospital, Port Harcourt, Rivers state, Nigeria.

Subjects recruited into the study were adult volunteers between the ages of 18 to 65 years with the ability to understand and provide informed consent.

\section{Inclusion criteria for HIV treatment-naïve subjects}

- An established HIV diagnosis (previous documentation)

- Patient has never been on antiretroviral therapy

- Negative plasma pregnancy test for females of child-bearing potential.

\section{Inclusion criteria for HIV treatment-experienced subjects}

- An established HIV diagnosis (previous documentation)

- Patient has been on antiretroviral therapy

- Negative plasma pregnancy test for females of child-bearing potential.

\section{Exclusion criteria from the study}

- $\quad<18$ or $>65$ years.

- History of an existing liver disease.

- Essential hypertension.

- Insulin and non-insulin dependent diabetes mellitus.

- Pregnant or breast feeding females (negative plasma pregnancy test).

- Women on oral contraceptive pills.

- Known bleeding or clotting disorders including history of deep vein thrombosis, pulmonary embolism or haemophilia.

- Hepatitis B or hepatitis C infection.

- Current use of anticoagulant therapy.

- Concurrent malignancy, requiring cytotoxic chemotherapy or radiation therapy.

- Nephrotic syndrome
A written consent was obtained from each participant, who was asked to fill the structured questionnaires to obtain demographic data, with assistance given, if necessary.

Blood was collected after the relevant information was recorded in the questionnaire.

\section{METHODOLOGY}

A commercial assay kit; ELISA Kit for DDimer (D2D) manufactured by Uscn Life Science Incorporated $^{\mathrm{R}}$ USA was used to determine the D-dimer level. A TC96+ ELISA microplate reader manufactured by Ceco diagnostic ${ }^{\mathrm{R}}$ USA was also used for the assay.

CD4+ T-cell count was evaluated using the Partec Cyflow counter-1, a single-platform, threeparameter (SSC plus two-colour fluorescence) desktop volumetric flow cytometer. The reagents and protocol for CD4 T-lymphocyte count were obtained from Partec.

Data was analysed using statistical soft ware package-SPSS version 20, Microsoft excel spread sheet. Descriptive and inferential statistics (Student T-test, Analysis of Variance (ANOVA), and Chi Square, Pearson correlation coefficient (r) were used as appropriate. $\mathrm{P}$-values $\leq 0.05$ shall be used to define level of significance.

\section{RESULT}

Eighty (80) HIV-positive adults were enrolled, 40 receiving HAART (HAART-experienced) and 40 who had never been exposed to HAART (HAARTnaïve). The HIV positive subjects have a total of 32 males and 48 females. Both HAART-naive and HAART-experienced subjects have 16 males (40\%) and 24 females $(60 \%)$ each.

The HAART-naïve and experienced subjects were mainly business men and women with $70 \%$ and $67.5 \%$ respectively.

The ages of the HAART-naïve and experienced subjects ranged from 18 to 59 years with a mean age of $35.16 \pm 7.82$ years. There was no significant difference between the mean ages of HAART-naïve (34.55 \pm 9.08 years) and HAART-experienced subjects (35.78 \pm 6.37 years), $\mathrm{P}=0.487$. The majority of the subjects $(47.5 \%)$ are in the age range of 26-35 years giving the highest prevalence of HIV positive subjects at $47.5 \%$ in this age group. There is no significant difference between mean ages of male (37.22 \pm 7.81 years) and female (33.79 \pm 7.60 years) subjects, $\mathrm{P}=0.56$ Table-1.

On the influence of HAART status on D-dimer level, mean D-dimer level was found to be significantly higher in HAART-naïve subjects than HAARTexperienced subjects, $389.85 \pm 217.61 \mathrm{ng} / \mathrm{ml}$ and $288.35 \pm 129.12 \mathrm{ng} / \mathrm{ml}$ respectively, $\mathrm{P}=0.013$ Table 2 . 
The mean CD4+ T-cell count of HAARTnaïve subjects was $379.33 \pm 287.25$ cell/ul and for HAART-experienced subjects was $387.55 \pm 334.85$ cell/ul. Their mean difference was not statistically significant $(\mathrm{P}=0.906)$ Table-2.

CORRELATION BETWEEN D-DIMERS AND CD4+ T-CELL COUNT IN THE HAART NAIVE PATIENTS

Table-1: Socio-Demographic Data of HAART-naïve and HAART-experienced subjects

\begin{tabular}{|c|c|c|c|c|c|c|c|}
\hline \multirow{3}{*}{\multicolumn{2}{|c|}{ Socio Demographic Data }} & \multicolumn{4}{|c|}{ HIV POSITIVE } & \multirow[t]{3}{*}{$\mathrm{Chi}^{2}$} & \multirow{3}{*}{$\begin{array}{l}\text { P- } \\
\text { value }\end{array}$} \\
\hline & & \multicolumn{2}{|c|}{$\begin{array}{l}\text { HAART- } \\
\text { NAIVE }\end{array}$} & \multicolumn{2}{|c|}{$\begin{array}{l}\text { HAART- } \\
\text { EXPERIENCED }\end{array}$} & & \\
\hline & & $\mathbf{N}$ & $(\%)$ & $\mathbf{N}$ & $(\%)$ & & \\
\hline \multirow[t]{5}{*}{ Age Group (years) } & $18-25$ & 7 & $(17.5)$ & 1 & $(2.5)$ & \multirow[t]{5}{*}{6.182} & \multirow[t]{5}{*}{$0.166^{+}$} \\
\hline & $26-35$ & 17 & $(42.5)$ & 21 & $(52.5)$ & & \\
\hline & $36-45$ & 11 & $(27.5)$ & 14 & $(35.0)$ & & \\
\hline & $46-55$ & 4 & $(10.0)$ & 4 & $(10.0)$ & & \\
\hline & $56-60$ & 1 & $(2.5)$ & 0 & $(0.0)$ & & \\
\hline \multirow[t]{2}{*}{ Sex } & Male & 16 & $(40.0)$ & 16 & $(40.0)$ & \multirow[t]{2}{*}{0.000} & \multirow[t]{2}{*}{1.000} \\
\hline & Female & 24 & $(60.0)$ & 24 & $(60.0)$ & & \\
\hline \multirow[t]{8}{*}{ Occupation } & CIVIL SERVANT & 6 & $(15.0)$ & 5 & $(12.5)$ & \multirow[t]{8}{*}{4.970} & \multirow[t]{8}{*}{$0.823^{+}$} \\
\hline & CLERGY & 0 & $(0.0)$ & 1 & $(2.5)$ & & \\
\hline & HOUSE HELP & 1 & $(2.5)$ & 0 & $(0.0)$ & & \\
\hline & HOUSEWIFE & 0 & $(0.0)$ & 2 & $(5.0)$ & & \\
\hline & RETIRED TEACHER & 0 & $(0.0)$ & 1 & $(2.5)$ & & \\
\hline & STUDENT & 2 & $(5.0)$ & 2 & $(5.0)$ & & \\
\hline & TRADER & 28 & $(70.0)$ & 27 & $(67.5)$ & & \\
\hline & UNEMPLOYED & 3 & $(7.5)$ & 2 & $(5.0)$ & & \\
\hline \multirow[t]{2}{*}{ Do you take alcohol? } & $\mathrm{NO}$ & 19 & $(47.5)$ & 28 & $(70.0)$ & \multirow[t]{2}{*}{4.178} & \multirow[t]{2}{*}{$0.041^{*}$} \\
\hline & YES & 21 & $(52.5)$ & 12 & $(30.0)$ & & \\
\hline \multirow[t]{2}{*}{ Do you Smoke? } & $\mathrm{NO}$ & 38 & $(95.0)$ & 39 & $(97.5)$ & \multirow[t]{2}{*}{0.346} & \multirow[t]{2}{*}{0.556} \\
\hline & YES & 2 & $(5.0)$ & 1 & $(2.5)$ & & \\
\hline \multirow{4}{*}{$\begin{array}{lc}\text { BMI } & \text { Class } \\
\text { Weight } / \text { Height }^{2}\left(\mathrm{Kg} / \mathrm{m}^{2}\right)\end{array}$} & Underweight $(<18.5)$ & 8 & $(20.0)$ & 5 & $(12.5)$ & \multirow[t]{4}{*}{1.245} & \multirow[t]{4}{*}{0.742} \\
\hline & Normal Weight (18.5-24.9) & 20 & $(50.0)$ & 20 & $(50.0)$ & & \\
\hline & Overweight (25-29.9) & 9 & $(22.5)$ & 10 & $(25.0)$ & & \\
\hline & Obese $(\geq 30)$ & 3 & $(7.5)$ & 5 & $(12.5)$ & & \\
\hline
\end{tabular}

Table-2: HAART Status

\begin{tabular}{|l|l|l|l|l|}
\hline Parameters & $\begin{array}{l}\text { HAART-Naïve N=40 } \\
\text { Mean }( \pm \text { SD) }\end{array}$ & $\begin{array}{l}\text { HAART-Experienced N=40 } \\
\text { Mean }( \pm \text { SD })\end{array}$ & t & P-value \\
\hline CD4 $^{+}$Count (cells/ul) & $379.33( \pm 287.25)$ & $387.55( \pm 334.85)$ & -0.118 & 0.906 \\
\hline D-dimer $(\mathrm{ng} / \mathrm{ml})$ & $389.85( \pm 217.61)$ & $288.35( \pm 129.12)$ & 2.537 & $0.013^{*}$ \\
\hline
\end{tabular}

Table-3: Correlation between D-dimer and CD4+ T-cell count in HAART Naïve patients

\begin{tabular}{|l|l|l|l|}
\hline Parameter & & D-dimer & CD4 Count \\
\hline D-dimer & Correlation & 1 & -0.196 \\
\cline { 2 - 4 } & $P$-value & & 0.225 \\
\hline CD4 Count & Correlation & -0.196 & 1 \\
\cline { 2 - 4 } & $P$-value & 0.225 & \\
\hline
\end{tabular}

Table-4: Correlation between D-dimer and CD4+ T-cell count in HAART Experienced patients

\begin{tabular}{|l|l|l|l|}
\hline Parameter & & D-dimer & CD4 Count \\
\hline \multirow{2}{*}{ D-dimer } & Correlation & 1 & 0.031 \\
\cline { 2 - 4 } & P-value & & 0.850 \\
\hline CD4 Count & Correlation & 0.031 & 1 \\
\cline { 2 - 4 } & $P$-value & 0.850 & \\
\hline
\end{tabular}




\section{DISCUSSION}

The purpose of this study was to determine the correlation between D-dimer levels and CD4+ $\mathrm{T}$ cell count in HIV treatment-naïve and treatmentexperienced patients in Port-Harcourt, Nigeria.

Several studies have shown that D-dimer levels are elevated in HIV infection and that the high levels of D-dimer observed in HAART-naïve patients is reduced by effective ARV therapy [26, 32-34]. HIV infection is a well recognized prothrombotic condition and D-dimer has also been associated with several clinical outcomes, including venous thromboembolism (VTE), cardiovascular disease (CVD), and all cause mortality [27, 35].

In this study, the D-dimer level was found to be significantly elevated in HIV treatment-naïve subjects in comparison to the HIV treatmentexperienced subjects $(\mathrm{P}=0.013)$. The mean $\mathrm{D}$-dimer level of HAART-naive subjects was $389.85 \pm 217.61 \mathrm{ng} / \mathrm{ml}$ and in HAART- experienced subjects was $288.35 \pm 129.12 \mathrm{ng} / \mathrm{ml}$. The observed Ddimer levels elevation in HIV infection in this study is in keeping with previous studies by Kuller [27], Neuhaus [32], Baker [36], Musselwhite et al., [35] and others.

A strong association between HIV replication and raised D-dimer levels has been demonstrated.

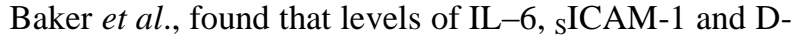
dimer were $65-70 \%$ higher in HIV-infected participants ( $\mathrm{P} \leq 0.02$ for all markers) than uninfected controls and these were statistically significantly higher in the HIVinfected study subjects than control [36]. Neuhaus et $a l$, in a comparison of HIV-infected participants from SMART with matched control subjects from the Coronary Artery Risk Development in Young Adult study (CARDIA) and multi-ethnic study of Atherosclerosis (MESA), levels of hsCRP, IL-6 and Ddimer ranged from $50 \%$ to over $100 \%$ higher in individuals with HIV infection [32]. Kuller et al., suggested that increase in D-dimer level could be as a result of HIV replication with induced activation of inflammatory and coagulation pathways [27]. The mechanisms involved are multifactorial and complex.

Highly active antiretroviral therapy (HAART) can suppress HIV replication for extended periods resulting in substantial reductions in chronic immune system activation and inflammatory cytokine production leading to a reduction in D-dimer levels and mortality in HAART-experienced patients [36].

Several studies have indicated that HAART reduces the level of biomarkers, including D-dimer, in HIV patients. El-Sadr et al found that levels of hs CRP, IL-6 and D-dimer were reduced by effective ARV therapy [26]. Baker et al., observed a significant reduction in D-dimer but not IL- 6 and hs CRP after starting ARV therapy, while interruption of ARV therapy led to an increase in these biomarkers [36]. Kuller et al., also demonstrated an increase in these biomarkers upon discontinuation of ARV therapy, and the increase was found to be associated with an increase in HIV-RNA levels [7]. In other studies by Hougaard et al., [37], Hamlyn et al., [38], Kaplan et al., [39] and in the STACCATO trial [39] reduced D-dimer levels were also observed in HIV treatment-experienced patients on HAART.

Neuhaus et al., in a comparison of inflammation biomarkers observed a significantly higher level of markers including IL-6, CRP and Ddimer in HIV positive subjects both on and off ARV therapy compared with HIV negative control, suggesting that viral suppression alone may not be sufficient to counter the factors driving inflammation in this population [32]

It was also observed in this study that HAART-experienced subjects have slightly higher mean $\mathrm{CD}_{4}+\mathrm{T}$-cell count $(387.55 \pm 334.85$ cells/ul) than HAART-naïve subjects $(379.33 \pm 287.25$ cells/ul $)$, though this difference was not statistically significant (P $=0.906)$. This could be explained by the fact that HIV infection leads to a specific decline in the $\mathrm{CD} 4^{+}$helper $\mathrm{T}$ cells, resulting in inversion of the normal CD4/CD8 $\mathrm{T}$-cell ratio. The major mechanism for $\mathrm{CD} 4+\mathrm{T}$ cell depletion is programmed cell death (apoptosis), which can be induced by HIV through multiple pathways [4042]. The HAART-experienced subjects has been associated with significant and prolonged immunologic reconstitution, characterized by increased CD4+ T-cell count, reduced opportunistic infections and prolonged survival $[43,44]$. While in HAART-naive individuals HIV infection is typically characterized by a rise in plasma HIV RNA (viral load) and a decline in CD4+ Tcell count. If left untreated, this eventually leads to opportunistic infections, development of AIDS and AIDS-related deaths [45, 46].

In his study, Erhabor et al observed that after 12 weeks of HAART in HIV infected subjects and untreated HIV infected controls there was a mean increase in CD4+ T-cell count of 39 cells/ul in subjects on HAART while untreated controls showed a mean decline of 12 cells/ul [47]. Jeremiah et al., [48] and Owiredu et al., [49], in similar studies also found that HAART improves CD4+T-cell count.

No correlation was observed between CD4+ T-cell count and D-dimer level in HAART-experienced and HAART-naïve subjects with $\mathrm{r}=0.031, \mathrm{P}=0.850$ and $\mathrm{r}=-0.196, \mathrm{P}=0.225$ respectively. The interplay between D-dimer levels, CD4+ T-cell counts and plasma HIV RNA is complex with dynamic changes after ART initiation [36]. Jeremiah et al., observed a negative correlation between CD4+ T-cell count and D-dimer level in HAART-experienced and HAART naïve 
subjects [48]. While Borges et al., observed a positive correlation between CD4+ T-cell count and D-dimer level in HAART-experienced subjects, which was surprising and counter-intuitive [50].

An association between CD4+ T-cell count and D-dimer levels has also been observed in several other studies, Crum-Cianflone et al., [28] and Rasmussen et al., [51] found that risk of Venous Thromboembolism are associated with low CD4+ Tcell counts. Ahonkai et al., [52] and Saif et al., [29] in previous studies also found a significantly increased risk of VTE in HIV infected patients with a low CD4+T-cell count (below 500 and 200 cells/ul respectively). This appears to be a result of immune / inflammatory activation causing increased D-dimer concentrations, which induces a hypercoagulable state. In contrast, Jacobsen et al found no association between CD4+ T-cell count and risk of VTE [53].

\section{CONCLUSION}

The study has been able to document the presence of elevated D-dimer level among HIV treatment-naïve patients in comparison to HIV treatment-experienced patients in Port-Harcourt, Nigeria. Data from this study also suggest that HAART reduces D-dimer level significantly in HAARTexperienced subjects, thereby reducing the risk of thrombosis. These findings are in support of existing literatures.

It was also observed in this study that HAART-experienced subjects have slightly higher mean $\mathrm{CD}_{4}+\mathrm{T}$-cell count than HAART-naïve subjects though this difference was not statistically significant.

However, no correlation was observed between CD4+ T-cell count and D-dimer level in HAART-experienced and HAART-naïve subjects.

\section{RECOMMENDATION}

Since the subjects in this present study are few, a cohort study using a larger population to confirm these findings is recommended.

It is suggested that D-dimer and CD4+ T-cell count should also be further studied to ascertain its usefulness in assessing risk of thrombosis in HIV infection.

Finally, a risk stratification system or screening tool for VTE should be developed for HIV patients, as this will help to reduce morbidity and mortality. This system should may involve CD4+ T-cell count and D-dimer assay, since these investigations are less expensive and easily accessible in a resourceconstrained environment like Nigeria.

\section{LIMITATIONS OF STUDY}

1. Cross-sectional study design which resulted in our inability to describe associations for Ddimer level and CD4 count overtime (unable to account for variations over time).

2. As a consequence of the small sample size some associations may have been missed.

\section{REFERENCES}

1. Joint United Nations Programme on HIV/AIDS (UNAIDS): Report on the Global AIDS Epidemic 2010. Epidemic update: Available; http://www.unaids.org/sites/default/files/media_as set/20101123_globalreport_en_1.pdf;16-61.

Accessed 12 ${ }^{\text {th }}$ December 2011.

2. Global AIDS response progress report (GARPR) 2012: January - December 2011 reporting period. National Agency for the Control of AIDS Federal Republic of Nigeria; 15-18.

3. USAID Nigeria; HIV/AIDS and Tuberculosis: Available; http://nigeria.usaid.gov/program/3. Accessed 12th June 2012.

4. UNDP. (2011). Human Development Report $2011 . \quad$ Available; http://hdrstats.undp.org/en/countries/profiles/NGA .html. Accessed 12th June 2012.

5. Hoffmann, C., \& Rockstroh, J. K. (2011). HIV Medicine 2011. Available; www.hivbook.com. Accessed on the 12th December 2011.

6. Alizon, S., von Wyl, V., Stadler, T., Kouyos, R. D., Yerly, S., Hirschel, B., ... \& Rauch, A. (2010). Phylogenetic approach reveals that virus genotype largely determines HIV set-point viral load. PLoS pathogens, 6(9):e1001123.

7. Adoga, M. P., Nimzing, L., Mawak, J. D., \& AGWALE, S. (2010). Human Immunodeficiency Virus Types 1 and 2: Sero-prevalence and Risk Factors Among a Nigerian Rural Population of Women of Child-bearing Age. SEMJ, 11(1):29-33.

8. Barré-Sinoussi, F., Chermann, J. C., Rey, F., Nugeyre, M. T., Chamaret, S., Gruest, J., ... \& Rozenbaum, W. (1983). Isolation of a Tlymphotropic retrovirus from a patient at risk for acquired immune deficiency syndrome (AIDS). Science, 220(4599), 868-871.

9. Clavel, F., Guetard, D., Brun-Vezinet, F., Chamaret, S., Rey, M. A., Santos-Ferreira, M. O., ... \& Rouzioux, C. (1986). Isolation of a new human retrovirus from West African patients with AIDS. Science, 233(4761), 343-346.

10. Evatt, B. L. (2007). The tragic history of AIDS in the hemophilia population, 1982 1984. Occasional Papers, (6). Journal Thromb Haemost, 4(11):2295-2301.

11. Reid, G. E. (2010). Hematologic manifestation of acquired immunodeficiency syndrome: Williams hematology $8^{\text {th }}$ edition, New York Mc graw-Hill. 1175-1198.

12. United Nations General Assembly Special Session (UNGASS): country progress report: Nigeria 
2010.

Available;

http://data.unaids.org/pub/Report/2010/nigeria_20

10_country_progress_report_en.pdf. Accessed 12th June 2012.

13. Egesie, J., \& Egesie, G. (2011). Seroprevalence of Human Immunodeficiency Virus (HIV) Among Blood Donors in Jos - Nigeria, HIV-infection Impact, Awareness and Social Implications of living with HIV/AIDS, Eugenia Barros (Ed.), ISBN: 978-953-307-343-9, InTech, Available from: http://www.intechopen.com/books/hivinfection-impact-awareness-and-social-

implications-of-living-with-hiv-

aids/seroprevalence-of-human-immunodeficiencyvirus-hiv-among-blood-donors-in-jos-

nigeria.Accessed 28th June 2012.

14. Ejele, O. A., Erhabor, O., \& Nwauche, C. A. (2005). Trends in the prevalence of some transfusion-transmissible infections among blood donors in Port Harcourt, Nigeria. Haema, 8(2), 273-277.

15. WHO/UNAIDS/UNICEF. (2011). Global HIV/AIDS Response: Epidemic update and health sector progress towards Universal Access 2011. Available

http://www.who.int/hiv/pub/progress_report2011/ en/index.html. Accessed 12th June 2012.

16. The World Bank 'West Africa HIV/AIDS Epidemiology and Response Synthesis: 2008;62. Available;

http://siteresources.worldbank.org/INTHIVAIDS/ Resources/375798

1132695455908/WestAfricaSynthesisNov26.pdf. Accessed 28th June 2012.

17. Badley, A. D., Pilon, A. A., Landay, A., \& Lynch, D. H. (2000). Mechanisms of HIV-associated lymphocyte apoptosis. Blood, The Journal of the American Society of Hematology, 96(9), 29512964.

18. Sauce, D., Larsen, M., Fastenackels, S., Pauchard, M., Ait-Mohand, H., Schneider, L., ... \& Bailey, M. (2011). HIV disease progression despite suppression of viral replication is associated with exhaustion of lymphopoiesis. Blood, The Journal of the American Society of Hematology, 117(19), 5142-5151.

19. Phillips, A. N., \& Lundgren, J. D. (2006). The CD4 lymphocyte count and risk of clinical progression. Current opinion in HIV and AIDS, 1(1), 43-49.

20. Zhou, J., Kumarasamy, N., \& TREAT Asia HIV Observational Database. (2005). Predicting shortterm disease progression among HIV- infected patients in Asia and the Pacific region: preliminary results from the TREAT Asia HIV Observational Database (TAHOD). HIV medicine, 6(3), 216-223.

21. Goujard, C., Bonarek, M., Meyer, L., Bonnet, F., Chaix, M. L., Deveau, C., ... \& Rouzioux, C. (2006). CD4 cell count and HIV DNA level are independent predictors of disease progression after primary HIV type 1 infection in untreated patients. Clinical Infectious Diseases, 42(5), 709715.

22. Crowe, S., Turnbull, S., Oelrichs, R., \& Dunne, A. (2003). Monitoring of human immunodeficiency virus infection in resource-constrained countries. Clinical infectious diseases, 37(Supplement_1), S25-S35.

23. Levine, A. M., Vigen, C., Gravink, J., Mack, W., Watts, C. H., \& Liebman, H. A. (2006). Progressive prothrombotic state in women with advancing HIV disease. JAIDS Journal of Acquired Immune Deficiency Syndromes, 42(5), 572-577.

24. Lijfering, W. M., Sprenger, H. G., Georg, R. R., van der Meulen, P. A., \& van der Meer, J. (2008). Relationship between progression to AIDS and thrombophilic abnormalities in HIV infection. Clinical Chemistry, 54(7), 1226-1233.

25. Adam, S. S., Key, N. S., \& Greenberg, C. S. (2009). D-dimer antigen: current concepts and future prospects. Blood, The Journal of the American Society of Hematology, 113(13), 2878 2887.

26. Strategies for Management of Antiretroviral Therapy (SMART) Study Group. (2006). CD4+ count-guided interruption of antiretroviral treatment. New England Journal of Medicine, 355(22), 2283-2296.

27. Kuller, L. H., Tracy, R., Belloso, W., De Wit, S., Drummond, F., Lane, H. C., ... \& Paton, N. I. (2008). Inflammatory and coagulation biomarkers and mortality in patients with HIV infection. PLoS medicine, 5(10);5(10): 203.

28. Crum-Cianflone, N. F., Weekes, J., \& Bavaro, M. (2008). Thromboses among HIV-infected patients during the highly active antiretroviral therapy era. AIDS patient care and STDs, 22(10), 771-778.

29. Saif, M. W., Bona, R., \& Greenberg, B. (2001). AIDS and thrombosis: retrospective study of 131 HIV-infected patients. AIDS patient care and STDS, 15(6), 311-320.

30. Funderburg, N. T., Mayne, E., Sieg, S. F., Asaad, R., Jiang, W., Kalinowska, M., ... \& Douek, D. C. (2010). Increased tissue factor expression on circulating monocytes in chronic HIV infection: relationship to in vivo coagulation and immune activation. Blood, The Journal of the American Society of Hematology, 115(2), 161-167.

31. Paffen, E., Vos, H. L., \& Bertina, R. M. (2004). Creactive protein does not directly induce tissue factor in human monocytes. Arteriosclerosis, thrombosis, and vascular biology, 24(5), 975-981.

32. Neuhaus, J., Jacobs Jr, D. R., Baker, J. V., Calmy, A., Duprez, D., La Rosa, A., ... \& Shlipak, M. G. (2010). Markers of inflammation, coagulation, and renal function are elevated in adults with HIV infection. The Journal of infectious diseases, 201(12), 1788-1795. 
33. Ananworanich, J., Gayet-Ageron, A., Le Braz, M., Prasithsirikul, W., Chetchotisakd, P., Kiertiburanakul, S., ... \& Cavassini, M. (2006). CD4-guided scheduled treatment interruptions compared with continuous therapy for patients infected with HIV-1: results of the Staccato randomised trial. The Lancet, 368(9534), 459-465.

34. Sodora, D. L., \& Silvestri, G. (2008). Immune activation and AIDS pathogenesis. Aids, 22(4), 439-446.

35. Musselwhite, L. W., Sheikh, V., Norton, T. D., Rupert, A., Porter, B. O., Penzak, S. R., ... \& Sereti, I. (2011). Markers of endothelial dysfunction, coagulation and tissue fibrosis independently predict venous thromboembolism in HIV. AIDS (London, England), 25(6), 787-795.

36. Baker, J. V., Neuhaus, J., Duprez, D., Kuller, L. H., Tracy, R., Belloso, W. H., ... \& Lundgren, J. (2011). Changes in inflammatory and coagulation biomarkers: a randomized comparison of immediate versus deferred antiretroviral therapy in patients with HIV infection. Journal of acquired immune deficiency syndromes (1999), 56(1):3643.

37. Haugaard, A. K., Lund, T. T., Birch, C., Rönsholt, F., Trøseid, M., Ullum, H., ... \& Ostrowski, S. R. (2013). Discrepant coagulation profile in HIV infection: elevated D-dimer but impaired platelet aggregation and clot initiation. Aids, 27(17), 27492758.

38. Hamlyn, E., Fidler, S., Stöhr, W., Cooper, D. A., Tambussi, G., Schechter, M., ... \& Porter, K. (2014). Interleukin-6 and D-dimer levels at seroconversion as predictors of $\mathrm{HIV}-1$ disease progression. Aids, 28(6), 869-874.

39. Kaplan, R. C., Landay, A. L., Hodis, H. N., Gange, S. J., Norris, P. J., Young, M., ... \& Parrinello, C. M. (2012). Potential cardiovascular disease risk markers among HIV-infected women initiating antiretroviral treatment. Journal of acquired immune deficiency syndromes (1999), 60(4), 359.

40. Alimonti, J. B., Ball, T. B., \& Fowke, K. R. (2003). Mechanisms of CD4+ T lymphocyte cell death in human immunodeficiency virus infection and AIDS. Journal of general Virology, 84(7), 1649-1661.

41. Grossman, Z., Meier-Schellersheim, M., Sousa, A. E., Victorino, R. M., \& Paul, W. E. (2002). CD4+ T-cell depletion in HIV infection: are we closer to understanding the cause? Nature medicine, 8(4), 319-323.

42. McCune, J. M. (2002). Mechanisms of T-cell depletion and regeneration in HIV Disease: The PRN Notebook. 7(3):1-9. Available; www.prn.org. Accessed $11^{\text {th }}$ July 2012.

43. Ippolito, G., Galati, V., Serraino, D., \& Girardi, E. (2001). The changing picture of the HIV/AIDS epidemic. Annals of the New York Academy of Sciences, 946(1), 1-12.

44. Centers for Disease Control and Prevention (CDC. (2001). HIV and AIDS--United States, 19812000. MMWR. Morbidity and mortality weekly report, 50(21), 430-434.

45. Lyles, R. H., Muñoz, A., Yamashita, T. E., Bazmi, H., Detels, R., Rinaldo, C. R., ... \& Mellors, J. W. (2000). Natural history of human immunodeficiency virus type 1 viremia after seroconversion and proximal to AIDS in a large cohort of homosexual men. The Journal of infectious diseases, 181(3), 872-880.

46. Phillips, A. N., Lampe, F. C., Smith, C. J., Geretti, A. M., Rodger, A., Lodwick, R. K., ... \& Johnson, M. A. (2010). Ongoing changes in HIV RNA levels during untreated HIV infection: implications for CD4 cell count depletion. Aids, 24(10), 1561-1567.

47. Erhabor, O., Ejele, O. A., \& Nwauche, C. A. (2006). The effects of highly active antiretroviral therapy (HAART) of stavudine lamivudine and nevirapine on the CD4 lymphocyte count of HIVinfected Africans. The Nigerians experience. Nigerian journal of clinical practice, 9(2), 128-133.

48. Jeremiah, Z. A., Obazee, Y., Okogun, G. R., Adias, T. C., Mgbere, O., \& Essien, E. J. (2012). Impact of short-term antiretroviral therapy (START) on some fibrinolytic markers in HIVinfected Nigerian adults: preliminary findings from the START study. HIV/AIDS (Auckland, NZ), 4, 87-94.

49. Quaye, W. K. B. A., \& Addai-Mensah, A. N. (2011). Prevalence of anaemia and immunological markers among Ghanaian HAART-naïve HIVpatients and those on HAART. African Health Sciences, 11(1):2-15.

50. Lee, A. J., Fowkes, F. G. R., Lowe, G. D., \& Rumley, A. (1995). Determinants of fibrin Ddimer in the Edinburgh Artery Study. Arteriosclerosis, thrombosis, and vascular biology, 15(8), 1094-1097.

51. Rasmussen, L. D., Dybdal, M., Gerstoft, J., Kronborg, G., Larsen, C. S., Pedersen, C., ... \& Obel, N. (2011). HIV and risk of venous thromboembolism: a Danish nationwide population- based cohort study. HIV medicine, 12(4), 202-210.

52. Ahonkhai, A. A., Gebo, K. A., Streiff, M. B., Moore, R. D., \& Segal, J. B. (2008). Venous thromboembolism in patients with HIV/AIDS a case-control study. Journal of acquired immune deficiency syndromes (1999), 48(3), 310.

53. Jacobson, M. C., Dezube, B. J., \& Aboulafia, D. M. (2004). Thrombotic complications in patients infected with HIV in the era of highly active antiretroviral therapy: a case series. Clinical infectious diseases, 39(8), 1214-1222. 